\title{
Moldovan Security Politics: A Tale of Three Cities?
}

\author{
Dr. Graeme P. Herd *
}

To many outside observers Moldova - the poorest state in Europe - appears to exist in a time warp, in which the policies and practices of the Soviet era shape the organization of the armed forces, the conduct of security sector affairs, and the form of state structures, official procedures, and elite and popular opinion. Irrespective of aspirations to accession to membership in the European Union (EU) or the North Atlantic Treaty Organization (NATO), Moldova faces enormous challenges as it attempts to overcome the burden of its Soviet heritage and to reshape its security sector. Such challenges included making their armed forces - and more broadly the security sector-affordable in light of other priorities, appropriate to the strategic circumstances, and acceptable to society at large. One key obstacle to such progress is the existence and influence of a separatist Transdniestria project and its disruptive impact upon Moldovan security politics.

The Molotov-Ribbentrop Pact of 1939, followed by the annexation of the Baltic republics, Western Ukraine, and Moldova by the USSR in 1944-45, helped pave the way for the creation of an "outer empire" through the installation of Communist regimes in Central and Eastern Europe (CEE) between 1945 and 1948. The unofficial status of the Moldovan SSR as "breadbasket and vineyard" of the Soviet Union was to be sharply juxtaposed by their post-1991 experiences, as Moldovan links with the Soviet command-control economic system were shattered. Consequently, the independent Moldova emerged as an unstable, marginal, and peripheral entity - a forgotten backwater left to languish by a disinterested international community. It was the best of times; it was the worst of times: it was to be a tale of three cities.

In the post-Soviet period, the Russian Federation has successfully disentangled itself from the Baltic States and Western Ukraine, but it is still embroiled in Moldova. In many ways, Transdniestria — or Pridnestrovskaya Moldavskaya Respublika (PMR) might be considered the "Kaliningrad of the Black Sea region." This analogy is not to suggest that PMR is Russian sovereign territory: it is not, as Russia acknowledges. Nor is it to argue that Russia should renounce sovereignty over Kaliningrad: the Helsinki Final Acts must be upheld. It is, though, to argue that PMR is akin to Kaliningrad to the extent that tensions between Russia's geo-political and geo-economic interests are apparent in its approach to the region. It is also to suggest that a political settlement to

Dr. Graeme Herd is Associate Director, Senior Executive Seminar and Professor of CivilMilitary Relations at the George C. Marshall European Center for Security Studies, Garmisch-Partenkirchen Germany; a Research Associate of the Conflict Studies Research Centre (CSRC), Defence Academy UK; and an Associate Fellow of the "New Security Issues Programme," Chatham House, London. The views expressed in this article are those of the author alone and do not necessarily reflect the official policy or position of the George C. Marshall European Center for Security Studies, the United States Department of Defense, the German Ministry of Defense, or the United States and German Governments. All errors of fact and weaknesses of interpretation are mine alone. 
this frozen conflict might serve as a litmus test (or, in the Putin-Kaliningrad formulation, "a pilot project") that demonstrates and showcases the capacity for cooperation between Russia and the EU. Only EU-Russian cooperation can facilitate the reintegration of PMR into a stable and sovereign Moldova. Such reintegration might also serve as a template for the reintegration of South Ossetia, and Abkhazia into a sovereign Georgia.

The Moldova-PMR conflict was most violent in June 1992, with over 1000 casualties, and particularly heavy fighting in the towns of Dubasari and Bender on the Dniestr River. The Russian $14^{\text {th }}$ Army under General Lebed was deployed as a peacekeeping force, but it rapidly became unclear to what extent Moscow controlled Lebed at the Tiraspol HQ, and to what extent Lebed was able to exercise control over subunits during this period. On 21 July 1992, the presidents of Moldova and Russia signed a ceasefire, and a tripartite peacekeeping force came into being. The following April, the OSCE opened a long-term mission in Chisinau and provided a framework for a comprehensive conflict settlement.

This approach to the political settlement has facilitated the emergence of a de facto independent PMR. While such frozen conflicts represent potential "credibility traps" for external actors and institutions when they fail to resolve the conflicts, the failure to even attempt any serious resolution poses a credibility test to the international community and its institutions. PMR is diplomatically isolated and a haven for transnational criminals and possibly terrorists, but it appears to be economically sustainable.

The Tiraspol elite under the control of "President" Smirnov prefers the continuation of the status quo to settlement, and is using state-type institutions to consolidate power. Grigori Marakutsa, Speaker of the Supreme Soviet in Tiraspol, stated on 26 December 2003: "Every year we are getting closer to our international recognition."1 PMR has the attributes of a state: a Constitution, President, national bank and currency judiciary, army, police and militia, strong internal security services, national anthem, coat of arms, and a flag. It also exhibits foreign policy pretensions. On 4 October 2004, the three "foreign ministers" of Abkhazia, South Ossetia, and PMR accused the governments in Chisinau and Tbilisi of "violation of the existing security and stability system. Given these conditions, Russia holds in continuation the key position in prevention of sizeable armed conflicts. The attempts to discredit the Russian peace maintenance mission are determined by the will to revise and change the historical role of the Russian Federation, actions that could produce unpredictable and dangerous consequences spilling over the regional framework." They argued that only the Commonwealth of Independent States could negotiate a resolution to the conflicts between Chisinau and Tiraspol or between Tbilisi and Sukhumi and Tzchinvali. ${ }^{2}$

“No End in Sight," IWPR's Balkan Crisis Report, No. 524, 5 November 2004.

2 "Transnistria, Abkhazia and South Ossetia Claim that Moldova and Georgia Would Like to Use Force," BASA-PRESS, 5 October 2004. 
PMR can be considered a "super-presidential republic," in that all political power resides with the presidency. ${ }^{3}$ The president appoints and dismisses all heads of administration and ministers to the Cabinet of Ministers (which replaced the office of prime minister, and is chaired by the president), and an indeterminate legal environment is maintained. The PMR Minister of National Security, a Mr. Antiufeev, formerly headed an OMON unit in Latvia during the "January events" of 1991 and is currently wanted by Interpol for the murder of Latvian journalists during this period. He restored and reformed the Cossack forces in PMR, and is believed to be under the control of and in permanent consultation with Russian FSB personnel (he is a "structure" rather than a "personality") and is perceived to be the right hand of the Smirnov clan.

The impact of the PMR-Russian security service connection upon Russian foreign and security policy towards Moldova is difficult to characterize. As one report noted: "At its most mischievous, the Kremlin's strategy may view Transdniestria as a second version of Kaliningrad, the Russian enclave near Poland - in other words, a troublemaking outpost on the borders of NATO."4 On 2 September 2004, PMR marked the $13^{\text {th }}$ anniversary of secession from Moldova "with Soviet songs, self-praise, and a military parade in Tiraspol. The parade featured 'regular troops,' 'border guards,' militiamen, rapid reaction forces, and Russian Cossacks. Other military such as pilots, infantry, artillerists, radio and communication troops," and bomb disposal experts took part in the parade. A visiting Russian delegation, lead by the deputy chairman of the State Duma, Sergey Baburin, told Olvia-Press that "one genuine reality must be accepted: Moldova is today made of two states - the Moldovan Transnistrian Republic and the Republic of Moldova - while the Transnistrians have fully demonstrated their right to choose their fate alone."

Political and military levers of control in PMR are buttressed by a managed economic order, both legal and illegal. Sherriff Company, a corporation under the control of the president's son, is PMR's largest business. The Russian firm ITERA controls the majority of shares in the Moldovan Metallurgical Plant (at Ribnita), which generates two-thirds of the region's tax revenues, and the Cuciurgan power station and KVINT brandy factory also provide the PMR with "state" revenues. Elements of the Soviet-era military-industrial complex that was based in Transdniestria are still active. Some arms factories (for example, the Elektromash and Tochlitmash works) produce weapons for the Russian military, and it is alleged that secret military production lines and surplus

3 "Residents of Transnistria cannot elect their leaders democratically, and they are also unable to participate freely in Moldovan elections." See: Freedom House Report on Transnistria for 2004, http://www.freedomhouse.org/research/freeworld/2004/countryratings/moldova-trans nistria.htm. See also: "Severe Violations of Human Rights in the Transdnistrian Region of Moldova," Statement by the International Helsinki Federation for Human Rights (IHF) and the Moldovan Helsinki Committee, 11 August 2004, http://www.ihf-hr.org/documents/ doc_summary.php?sec_id=3\&d_id=3955.

4 "The hazards of $\overline{\mathrm{a}}$ long, hard freeze," The Economist, 19 August 2004, http://www.economist.com/world/europe/displaystory.cfm?story_id=3110979.

5 "Transnistria Marks $13^{\text {th }}$ Anniversary of Secession from Moldova with Military Parade in Tiraspol," BASA-PRESS, 2 September 2004. 
materials are sold on the black market. Romanian Foreign Minister Mircea Geoana, for example, characterized the PMR as "a black hole of trans-border organized crime, including drug smuggling, human trafficking [particularly women and children to the Balkans, UAE, Turkey, and Western European 'markets'], and arms smuggling." The 460 kilometers of the PMR segment of the Moldovan-Ukrainian border is widely considered to be particularly porous.

The European Parliament resolution on Moldova, passed on 18 December 2003, characterized the state as having a weak administration that lacks effective democratic controls, noted that eighty percent of the market is informal and that little tax revenue is raised, and charged that controls over the Eastern border were non-existent and the social system was ineffective. Moldova, for example, only accounts for a meager $0.04 \%$ of EU's imports.

The 1999 OSCE Istanbul Summit agreed that the deadline for the withdrawal of Russian troops and ammunition from PMR was 2002, despite opposition from Tiraspol. In December 2002, at the Porto OSCE Ministerial, the deadline for the withdrawal of Russian weapons from Transdniestria was extended until the end of 2003, and then subsequently further extended into 2004. Russia declared its "intention" to do this, "provided the necessary conditions are in place," so serving to underscore the ineffectiveness of the five-sided OSCE sponsored talks on conflict resolution.

The $14^{\text {th }}$ Army has been perceived as a Russian lever of control over PMR, and therefore over the strategic orientation of Moldova proper. However, it is increasingly clear to Moscow that new political levers of control need to be developed. The OSCE Porto Summit signaled that the West was less interested in Moldova, and that Russia was free to take the lead. After a visit to Moscow between 7-9 February 2003 by President Voronin of Moldova, the "Voronin Initiative" appeared on 11 February 2003. This plan was his contribution to a political settlement based on federal principles and appears to operate on the logic of, "You have the power, we have the control." The "Kozak Memorandum" was presented on 17 November 2003, and can be understood as the Russian political response to the diminishing utility of military levers of control in PMR. Dmitry Kozak, First Deputy Head of the Russian Presidential Administration (a personal representative of President Putin, and now his chief of staff in the presidential administration) introduced a "Memorandum on the Basic Principles of the State Structure of a United State." This suggested a "federation on a contractual basis" that would allow the right of PMR secession and recognition of PMR independence, and the "two equal subjects/two unit federation" formula allowed the possibility of a PMR veto of all federal laws.

On 5 November 2003, Voronin met with OSCE chairman Jaap de Hoop Scheffer (currently NATO Secretary-General) and began to reconsider his position on federalization plans. Although Voronin had initialed each page of the Kozak Memorandum, he had not signed it, allowing him to disavow it on 24 November 2003. At the OSCE summit Maastricht, held from 1-3 December, it became clear that Western OCSE states did not consider Moscow's approach constructive. The West rejected the Kozak Memorandum. The U.S. Secretary of State Powell praised the OSCE's "constructive 
multilateralism," and President Voronin highlighted the necessity of Moldovan integration into "Western" Europe as a policy priority.

As a result, it appears that President Voronin and his ruling Communist Party then came under pressure from Mr. Urekean, the mayor of Chisinau, who is an opposition party member and a likely contender in the presidential election (the president is elected by the $101 \mathrm{MPs}$, who will themselves be elected in the February 2005 parliamentary elections). As no party comes to power in Moldova without Russian financial and campaign support, the fact that the mayor recently visited Moscow-albeit for "hospital treatment"-was newsworthy. Voronin was facing an implicit choice: Moscow would back or threaten to back an opposition candidate and party unless Voronin ceased his attacks on the logic of the Kozak Memorandum. His choice was to cooperate with Moscow or run the risk of being replaced by an alternative Moscow-supported candidate. On 17 February 2004, without any publicity, the Moldovan Minister of Reintegration presented OSCE mediators with the "Chisinau view"- the Moldovan government's comments on the OSCE document that was the basis of the negotiations. However, the "Chisinau view" was "Kozak II" in all but name. Voronin appeared to accept this implicit deal.

Moldova is caught trying to balance stronger tendencies toward European integration with continued Russian influence (as embodied in the "Kozak Memo II"). As Vladimir Socor, a prominent analyst of Moldovan security politics, has asked, "What kind of political and security order are we to have in this long Moldovan sector? A Communist-run, remote-controlled Russian satellite, or a democratized and Europeanoriented neighbor? This is what's at stake in the controversy over 'federalization'." This question might best be understood as embodying the dualities present in the person of the president, and can be characterized as a battle between upholding Moldova's national interest and continuing to ensure his personal political viability and hold on power. By early to mid 2004, in the absence of a clear EU policy, even an optimist might well have concluded that Moldova's national interest will only be upheld as an unintended by-product of the political infighting between Voronin and Russian-backed opposition parties. Reorientation towards the West might well have occurred, but only by default rather than by design.

However, the ongoing low intensity "frozen conflict" between Chisinau and Tiraspol began to heat up as 2004 unfolded. The regime of visa sanctions against the PMR leadership was intensified in July 2004 in reaction to Tiraspol's harassment of Moldovan-language schools; tensions flared in the divided town of Tighina/Bendery in autumn 2004, when Transdniestrian militia seized control of a vital railway station. ${ }^{6}$

Thus, President Voronin's willingness to compromise Moldova's sovereignty, so apparent in late 2003, was reversed through 2004, mainly as a result of frustration at Tirispol's intransigence and unwillingness to fulfill agreed commitments. In October 2004, he stated that his administration would no longer negotiate with the Transdnistrian administration and noted that the idea of federalization was now to be considered

6 Nicholas Whyte, "In Search of a Solution," IWPR's Balkan Crisis Report, No. 524, 5 November 2004. 
outdated, confirming other conflict resolution methods would be applied. He stated that a multinational peace mission should replace Russian peacekeepers in Transdnistria: "instead of respecting the treaty and help Moldova settle this conflict, Russian forces support Smirnov and his regime." Current negotiations had produced no results and "Smirnov and the Russian and Ukrainian authorities are seeking to freeze the conflict and let the Transnistrian cement their independence." 7 This echoed an earlier statement in which he stressed: "All these years, the Transnistrian regime has been and will remain a puppet regime, because it is ruled from the capitals of Russia and Ukraine. A lasting settlement of the Transnistrian conflict depends in fact entirely on the Russian Federation's position. We want to clarify this position to the very end."

Given these new realities, what might Western policy makers within the EU do to help create and implement a policy that has a stronger focus and a greater chance of success? First, by 2007, Romania will be an EU member state (or by 2010, if delays arise) and the "soft security" threats that emanate from PMR will have become more obvious and less easy to dismiss - particularly as similar "soft security" threats in the Balkans hopefully diminish as Balkan reintegration into the Euro-Atlantic security order gathers pace. Second, as EU third-echelon enlargement in the Black Sea region (Moldova, Ukraine, Georgia) will be unlikely, EU contributions to the unification of Moldova can be presented as a compensatory alternative to membership. Third, as the Balkans stabilize and the ESDP gains operational confidence and strength, it will become harder to avoid the logic of the deployment of civilian and/or military instruments in PMR. Fourthly, a failure to uphold the credibility of the EU's wider partnership policies will be exposed by inaction. The EU's European Neighbourhood Policy (ENP) was launched in May 2004. The aim of ENP is to promote prosperity and stability through the promise of the extension of "4 freedoms" to the EU's neighbors. The ENP has buttressed the existing contractual frameworks - Partnership and Cooperation Agreement (PCA) - which governs relations between the EU and Moldova. This policy needs support to become an effective instrument of stabilization and Moldova provides the opportunity and the challenge of inaction.

The EU currently deals with the Russia-EU agenda using a "basket of issues" approach - that is, separating economic issues, human rights, and political issues and negotiating on that basis. (Hence Chechen human rights abuses do not inconveniently disrupt the EU-Russia energy dialogue. $)^{9}$ By contrast, Russia has dealt with its neighbors

7 "Transnistria, Abkhazia and South Ossetia Claim that Moldova and Georgia Would Like to Use Force," BASA-PRESS, 5 October 2004. See also: "Voronin Confirms Refusal to Speak to Current Tiraspol Leaders, and Grows Cool to Federalization Idea," INFOTAG, 30 September 2004, http://www.azi.md/news?ID=31084: "Such talks are fruitless and counter-productive. We have analyzed the situation and found out the sides have already signed 99 documents. Moldova abides by $99 \%$ of them, and Transnistria - $1 \%$."

8 "President Voronin Says Moldova Refuses to Speak with Tiraspol in Previous Manner," INFOTAG, 3 September 2004: http://www.azi.md/news?ID=30689.

9 See Tuomas Forsberg and Graeme P. Herd, "The EU, Human Rights and the Russo-Chechen Conflict," Political Science Quarterly (2005) - forthcoming. 
by linking issue areas in which there are points of contention-for example, linking state payments of military pensioners to border ratification in turn to "human rights" abuses in the Estonian and Latvian cases. The EU should not adopt Russia's approach to Baltic policy as the guiding principle underpinning EU-Russian relations, linking the energy dialogue to PMR conflict resolution. Instead, it should attempt to achieveby the end of Putin's second presidential term - a solution. Just as with Kaliningrad, this will suggest that such a solution will have become the new litmus test for the cooperative capacity between Russia and the EU.

It is clear that the current OSCE-Russia-Ukraine moves to federalize Moldova, thereby giving greater legitimacy to PMR, will not be in the longer-term interests of the EU or NATO. However, while there are compelling reasons why the EU and NATO should focus on Moldova, it is not clear how this process will occur. Attempting to strong-arm Russia, even if successful, is simply one means to an end that requires a coordinated strategy by international actors in the region. Other obstacles remain: the precariousness of President Voronin's political power base; Ukraine's unwillingness to coordinate policy; and the ineffectiveness of EU and NATO policy-making in this region. Above all, the intransigence of the PMR authorities cannot be underestimated. In March 2004, Antiufeev stated his opposition to the introduction of EU peacekeepers to the region with the words: "We will kill them."

What might be done to persuade President Voronin not to give in to Russian threats to run a candidate against him in the February 2005 parliamentary elections? Would any initiative involve the West either running their candidate or supporting the Communist Party leader? If so, what impact might this have on relations with Russia? Is Ukraine prepared to close the PMR-Ukrainian border and deprive the illegal economy of its outlets? Some might argue that only regime change in Kiev-with Yushchenko replacing President Kuchma - would provide the precondition for such a reorientation. At the time of writing, the Ukrainian Presidential election enters the run-off period and so this question is open. Even were Yushchenko to be elected president, would he occupy the office but find himself unable to exert power? ${ }^{10}$

At present, the EU and NATO have no real strategy for dealing with states with little or no prospects for membership. However, change may be in the air. Is there a gradual acceptance in Brussels and Chisinau that a larger EU role is desirable? In early November 2004, Ambassador Ian Boag, the new chief of the European Commission Delegation to Moldova, based in Kiev, stated that the EU seeks a more active role in the PMR settlement process: "to develop practical actions aimed to create a favorable environment for settlement of the Transnistrian crisis."

At the same time, Moldovan officials at the OSCE Permanent Council in Vienna have invited the US and EU to become more actively involved in the settlement of the

10 James Sherr, "Ukrainian Elections: Themes and Variations," Conflict Studies Research Centre, UK Defence Academy, 25 October 2004, Number 04/32: ftp://csrc:130csr201@, csrc.ac.uk/csrc/frames/frames_page.htm.

11 "EU to play more active role in the Transnistrian conflict settlement," 8 November 2004, Basa-press: http://www.peacebuilding.md/monitor.htm?lang=en\&idm=418f20f17ef52. 
conflict in Transdniestria. ${ }^{12}$ They also called on Russia, Ukraine and Romania to support the declaration of stability and security for Moldova in order for Moldova to enter the Stability Pact during the OSCE ministerial council in Sofia, 6-7 December 2004. This initiative has the support of Javier Solana, the EU Foreign \& Security Policy Chief, and suggests a very real alignment of the Republic of Moldova and the EU. ${ }^{13}$ Such a tendency would be consolidated were the EU to open an office in Chisinau.

Despite such positive trends, without support from Moscow, Kiev and Tiraspol, the traditional EU and NATO economic and political carrot-and-stick approaches will remain ineffective, to say the least. This short analysis identifies many obstacles and challenges; unfortunately, it only points to the emergence of potential solutions, rather than the consolidation of such tendencies. For now at least, Moldova's security politics will continue to be a tale of three cities: Tiraspol, Kiev, and Moscow. When another three cites - namely the policy-making elites in Chisinau, Brussels, and Washington D.C.- play as large a role as the post-Soviet centers of power, a manageable resolution of this issue may at last be forthcoming. Until then, Moldova will remain at the very least a complex challenge for coherent, effective, and efficient EU and NATO policymaking and implementation in South East Europe.

12 "Moldova wants to alter format of Transdniestria settlement talks," 12 November 2004: http://www.interfax.com/com?item=Mold\&pg=0\&id=5769803\&req $=$.

13 “Javier Solana Thinks Declaration Signature Is Possible," INFOTAG, 29 October 2004: http://www.azi.md/news?ID=31517. 


\section{Bibliography}

Forsberg, Tuomas, and Graeme P. Herd. "The EU, Human Rights and the RussoChechen Conflict." Political Science Quarterly (2005).

Sherr, James. Ukrainian Elections: Themes and Variations In Conflict Studies Research Centre. UK Defence Academy, 2004.

Whyte, Nicholas. In Search of a Solution. IWPR's Balkan Crisis Report, 2004. 